\title{
腰神経根引き抜き損傷の一例
}

$\begin{array}{rll}\text { 山口赤十字病院整形外科 } & & \\ \text { 土 屋 邦 喜・佐々木 邦 雄 } \\ \text { 松 本 直 之・清 水 } \\ \text { 田 丸 卓 弥・眞 島 }\end{array}$

\section{Lumber Nerve Root Avulsion Report of a Case -}

by

\section{Kuniyoshi Tsuchiya, Kunio Sasaki, Naoyuki Matsumoto, Atsushi Shimizu, Takuya Tamaru and Yasushi Mashima \\ Department of Orthopaedic Surgery, Yamaguchi Red Cross Hospital}

Traumatic lumbosacral nerve root avulsion has been recognized as extremely rare, compared with traction injury of cervical lesion. This seems to due chiefly to the structural characteristics of the mechanism of lumbar girdle. But recently, with the development of high speed transport, so called high momentum injury has been increasing.

We report a case of a 58-year-old woman who sufferred from right 4 th lumbar nerve root avulsion in the traffic accident.

She had fractures of right pelvic ring and right transverse process of the 5th lumbar spine.

Mechanism of this injury seemed to be left side bending of lumbar spine and fiexion-abduction displacement of right thigh.

In treating a case of pelvic fractures associated with flaccid paralysis of lower leg, we must take into consideration an avulsion injury of the lumbar nerve root.

\section{は じめに}

腰部の神経根損傷は, 頸部に較べてその解剖学的特 性から発生頻度は比較的低いとされている，今回，当 科において第 4 腰神経根引き抜き損傷と診断された 1 症例を経験したので，その診断および治療経過に加え その発生頻度や発生メカニズムなどについて，考察を 加え報告する。

症例： 58 才，女性.

\section{主訴：右下肢脱力および歩行障害}

現病歴：昭和 61 年 3 月交通事故にて全身打撲扔上 び脳挫傷で 3 週間意識消失があった．約 1 年間のリハ ビリ後, 右下肢筋力の回復不十分で, 歩行障害が残り, 原因精査の目的で当科受診，入院となった。
入院時現症：全身状態とくに異常なし. 右下肢に筋 力低下, 右 PTR は消失, また, 戝に示す領域に知覚障 害を認める(図 1 )。

$\mathrm{X}$ 線所見: 腰椎単純撮影では右第 5 腰椎横突起骨折 および L5-S1 の狭小化，左への傾斜を認めるほかとく に異常所見を認めない.

骨盤単純撮影にて陳旧性と思われる右恥骨枝および 坐骨枝の骨折，また仙腸関節部には骨硬化像を認め, 受傷時の仙腸関節部への外力を疑わせる（図 2 ）。

ミエログラフィー：右下側臥位充満像にて右 $\mathrm{L} 3, \mathrm{~L}$ 4rootに椎間孔レベルで cyst 様途絶像を認めた。

臥位および立位前後像でも同レベルに meningocele を認める。 L3 は partial stop, また L2 もやや描出不良 である（図 3 ）。 


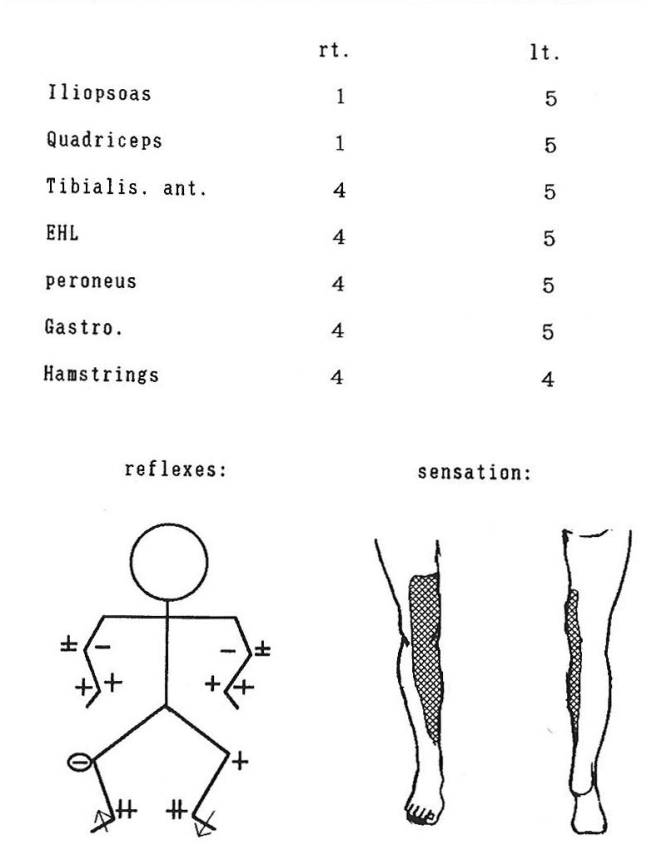

図 1 Neurological findings

muscle power of lower extremities
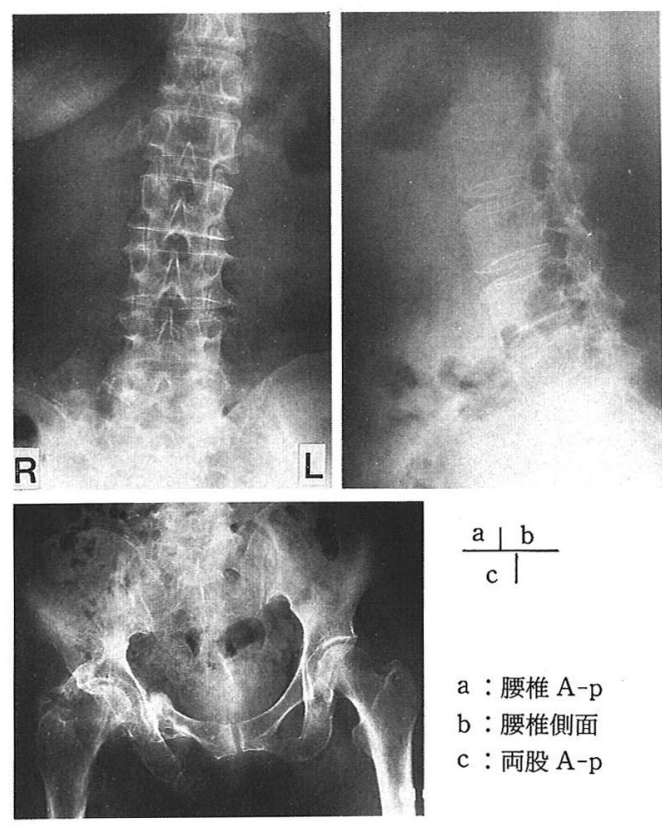

図 2 入院時単純レ線像

MCT：本例において MCT でははっきりした meningoceleの断面は示されなかった。

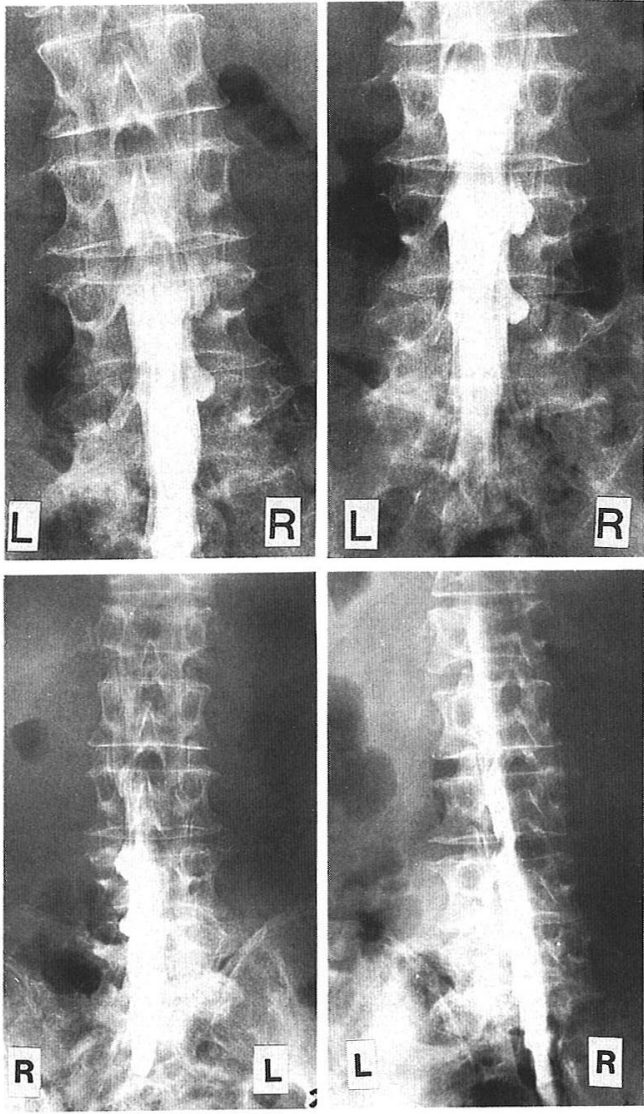

図 3 ミエログラフィー

$\mathrm{a}$ ：立位 A-P

$\mathrm{b}$ : 腹臥位 A-P

$c$ ：右下側臥位 A-P

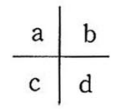

$\mathrm{d}$ : 左下側臥位 P-A

右 L4 levelに Cyst 様途絶像を認める.

Histamine flare test: L3 レベルでは注射後約 3 分 で注射部位の発赤が見られたが, flareの形成は見られ なかった。しかし，L4レベルでは注射後約 1 分より注 射部位を中心とした明らかな flare の形成が見られた。 結果として L4 histamine flare test 陽性に対し L3 は 同テスト陰性と判定. 以上の結果をふまえ右 L4 神経根 の引き抜き損傷と診断した。

$$
\text { 考察 }
$$

腰部神経根損傷は通常 2 力所以上の骨盤骨折に合併 することが多く, 高速交通機関の事故においてその多 くは発生する。白結果年令として若年男性にもっと 
表 1 Traumatic nerve root meningocele 報告例の障 害高位別分類

\begin{tabular}{c|c}
\hline \hline Level & 例 数 \\
\hline L 2 & 1 \\
L 3 & 3 \\
L 4 & 3 \\
L 5 & 12 \\
S 1 & 8 \\
S 2 & 2 \\
\hline
\end{tabular}

Reported cases : total 18 cases, 29 roots

(うち骨盤骨折を合併しない症例 6 例)
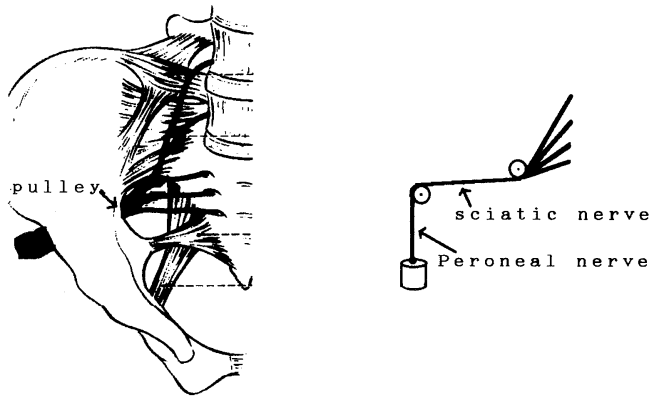

図 4 坐骨神経伸展のメカニズム

も多く発生する. 骨盤骨折に合併する神経損傷の頻度 は, 確定診断の付いた報告例が少なく明らかでないが 少なくとも頸部神経根の引き抜き損傷および腕神経叢 損傷よりはきわめて少ないとされている，その理由と して, 強大な下肢筋力のため, 外力による大腿部の大 きな動きは上肢に較べてはるかに起こりにくいこと, 深部にあるため体表からの直達外力を受けにくいこと が挙げられる。また全身的な症状を合併していること が多く casting などのためその発見が遅れがちになるこ とも，その 1 つの特徴と言えるであろう.

現在までに報告されているいわゆる外傷性の meningocele はわれわれの探し得た範囲では 18 例, 29 神経根 である1) 8)10) 13).

報告例を障害高位別に分類してみると, 圧倒的に L5 および S1 rootに多い（表 1)。発生のメカニズムとし て, 通常股関節の屈曲外転強制による sciatic notch を pulley とする坐骨神経の伸展が挙げられる6) (図 4). その他腰椎の側屈強制による神経根部での伸展張力も 発生原因として考えられる。

また, 骨盤骨折を合併しない症例が 18 例中 6 例と約 3 分の 1 におよび，引き抜き損傷が必ずしも骨盤骨折 に合併していないことは発生メカニズムとして, 外力
による伸展張力の作用を強く示唆するものと思われる. 先述のごとく L5, S1 root が多い理由として同レべ ルでもっとも神経根が foramen を通過する部位でその 蛇行が小さく走行が直線に近いことが挙げられる。し かし本症例に関しては単根性に L4 神経根が障害されて おりこれらの報告例から考えると珍しい型であるが, この理由については腰椎の左側屈強制に加え膝の屈曲 などの外力により大腿神経に伸展張力が加わった結果 でないかと推測する。

診断の中心はミエログラフィーの所見であるが, meningocele とその中に root shadow が証明されない 所見があれば root avulsion と考えてよいと思われる. しかし,造影剂として pantopaque を使用した場合, 手 術 (椎弓切除) を施行した例の約 $12 \%$ にミエロ所見と ope 所見の不一致, false positive を認めている.一方, metrizamide を使用した症例においては，このような false positive は報告されておらず,この点においては 現時点では metrizamide を含む水溶性造影剤の方が診 断に有用であると思われる ${ }^{14)}$.

また, MCTにおいて dural sack の断層が写り，内 部に root shadow を証明しない所見があれば, 診断は さらに確実になる。しかし MCT 診断に関しては，断 層間隔，スライス厚，撮影までの時間，撮影体位など さらに今後の検討が必要と思われる。

画像診断上重要な鑑別診断として，外傷に伴わない congenital cyst があり，その特徴としてょり高令者に 多く発見される，発生部位が多くの神経高位にわたる ことが多い, ミエロ上 cyst の中に root が造影されるこ とが多い，などがあげられる，実際上はミエロで cyst が証明されても，外傷の既往がなく，根の脱落症状を 伴っていなければまず congenital cyst と診断して問題 ないと思われる。その他，障害が後根神経節より高位 の，いわゆる avulsion か，あるいは神経節より末梢側 の節後損傷かを調べる手段として皮膚サーモグラフィ 一や histamine flare test が挙げられる。

\section{治 療 方 針}

root avulsion の症例においては, 社会復帰のための 代償運動や残存せる部位の機能訓練によるリハビリが 中心になる，ただし確定診断は直視下に確かめるほか はないという問題があり実際問題としては回復の可能 性も考えて，リハビリを行うことが重要であると考え $る^{8)}$. また，神経移行による機能再建も今後検討するべ 
きものと思っている.

\section{ま と め}

1. 右第 4 腰神経根引き抜き損傷と思われる 1 症例 を報告した。

2. 腰神経根引き抜き損傷はその解剖学的特性から 発生頻度は比較的低いとされているものの確定診断を 手術所見に待つほかないというその特殊性から正確な 発生頻度は明らかでない。

3. 高速交通機関の事故において発生することが多 くその多くは若年男性に発生する，骨盤骨折に合併す ることが多いが骨折を伴わない例も少なくない.

4. 障害レベルは L5, S1 がもっとも多い.

5. 発生のメカニズムとしては大腿部の屈曲一外転 強制による坐骨神経の伸展がもつとも有力である.

6. 診断にはミエログラフィーが有用である．また 造影剂としては水溶性造影剂が診断率が高いと思われ る.

\section{参 考 文 献}

1) Alker, G. J. Jr., Glasauer, F. E., Zoll, J. G. et al. : Myelographic Demonstration of Lumbosacral Nerve Root Avulsion. Radiology, 89 : 101-104, 1967.

2) Barbera, J.: Traumatic lumbosacral meningocele. J. Neurosurg., 46 : 536-541, 1977.

3) Barnett, H. G., Connolly, E. S.: Lumbosacral Nerve Root Avulsion-Report of a Case and Review of the Literature-. J. Trauma., 15: 532-535, 1975.

4) Carlson, D. H., Hoffman, H. B.: Lumbosacral Traumatic Meningocele Report of a Case. Neurology, 21 : 174-176, 1971.

5) Eisenberg, K. S. : Posterior Dislocation of the Hip Producing Lumbosacral Nerve-Root Avulsion. J. Bone and J. Surg., Vol. 54-A No. 5 : 1083-1086, 1972.

6) Finney, L.A., Wulfman, W. A.: Traumatic Intradural Lumbar Nerve Root avulsion with Associated Traction Injury to the Common Peroneal
Nerve. Am J. Roentgen, 84 : 952-957, 1960.

7) Goodell, C. L. : Neurological Deficits Associated with Pelvic Fractures. J. Neurosurg., 24 : 837-842, 1966.

8) Harris, W. R. : Avulsion of Lumbar Roots Complicating Fracture of the Pelvis. J. Bone and J. Surg., vol. 55-A, 1436-1442, 1973.

9) Huitinen, V. M. : Nerve Injury in Double Vertical Pelvic Fractures. Acta Chir Scand., 138: 571-575, 1972.

10) McLennan, J. E. : Traumatic Lumbar Nerve Root Meningocele. J. Neurosurg., 39: 528-532, 1973.

11) NosiK, W. A. : Intracranial Hypotension Secondary to Lumbar Nerve Sleeve Tear. JAMA, vol. 157 No. 13: 1110-1111, 1955.

12) Padberg, G., Coene LNM : Traumatic Disruption of the Sacral Root Sheath. J. Neurol. Neurosurg. Psychiatry, 38: 819-821, 1975.

13) Payne, R.F., Thomson JLG: Myelography in Lumbo-Sacral plexus injury. Br. J. Radiol., 42 : 840845, 1969.

14) Streiter, M. L. : Metrizamide Examination of Traumatic Lumbar Nerve Root Meningocele. Spine, Vol. 9 No. 1, 1984

質 問脊損センター 角田 信昭

L4 神経根の引き抜きということは, 大腿神経領域の 引き抜きとして L5, S1 神経根とは異なった受傷メカニ ズムも考えられます。

とくに hip joint の役割もあるていどあるかと思いま すが, 本症例にどのような受傷機転が想像されますか.

\section{解 答出口赤病院 土屋 邦喜}

受傷後当科受診まで相当の期間があったこともあり， 正確な受傷機序は明らかでないが，本症例においては 膝の強い屈曲など何らかの形で大腿神経に伸展張力が 加わった結果このような受傷形態になったものと考え ている. 